\title{
Mathematics Learning To Use Moodle-Based Hybrid Learning in SMA Negeri 1 Tembilahan Hulu
}

\author{
Mas`ud Zein ${ }^{1}$, Zukifli M. Nuh², Dardiri³, Musa Thahir ${ }^{4}$ \\ ${ }^{1}$ Riau Islamic State University Sultan Syarif Kasim, Indonesia \\ ${ }^{2}$ Riau Islamic State University Sultan Syarif Kasim, Indonesia \\ ${ }^{3}$ Riau Islamic State University Sultan Syarif Kasim, Indonesia \\ ${ }^{4}$ Riau Islamic State University Sultan Syarif Kasim, Indonesia
}

\section{ARTICLE'S}

INFORMATION

\section{Article history:}

Received: Nov-09-2019

Accepted: Nov-22-2019

\section{Keywords:}

Mathematics Learning

Hybrid Learning

Moodle

Mathematical Learning

Outcomes

\section{Corresponding address:}

Mas`ud Zein,

E-mail: mas’ud.zein@uin-suska.ac.id

\section{INTRODUCTION}

The development of information and communication technology today makes science as a 'commodity' as other economic items. The role of information and communication technology is becoming increasingly large and evident in today's modern world. The rapid development of technology should be accompanied by improvements in the quality of human resources. Mathematics education is one of the important elements in life that can support the improvement of the quality of human resources. Mathematics education that is provided for the future should pay attention to two objectives, namely the first objective which is formal and the second objective is material. Formal objectives, namely in the form of structuring reason and the personal formation of students and goals that are material in the form of the application of mathematics. These objectives are intended so that students are able to use mathematics in solving problems in everyday life. Students can use mathematical thought patterns in everyday life, so students know the benefits of learning mathematics [1]. These objectives are intended so that students are able to use mathematics in solving problems and use mathematical thinking 
patterns in everyday life, so students know the benefits of learning mathematics. Students also need to learn science that can emphasize structuring student understanding and communication as well as skills in applying mathematics. This shows that the mathematical ability of students is still very low. The low ability of high school students in understanding and interpreting mathematics is felt as a fairly complicated problem in teaching mathematics in schools.

Based on the Results TIMSS provides the fact that Indonesian students are still weak in mathematics. This is based on the fact of the mathematical ability of high school students in Indonesia according to international studies (Trend of International on Mathematics and Science Study/TIMSS), namely the results in 2011 showed that mathematics mastery of eighth grade students in Indonesia was ranked 38th out of 45 participating countries with an average score of 386. TIMSS 2015 results, Indonesia gets a mathematical score of 397 where the average TIMSS ranges around a score of 500, placing Indonesia at number 45 of 50 countries [2]. SMA Negeri 1 Tembilahan Hulu is one of the schools that implemented the 2013 curriculum. The observations of the researchers showed that students' mathematics learning outcomes are still low. The low student learning outcomes seen from the initial test results data given to students only amounted to $42.3 \%$ completing completeness. In addition, based on the survey results obtained information that that students learn in class on average only memorize, without recognizing and experiencing the lessons they learn directly and also students find it difficult to connect prior knowledge with the knowledge they have just learned now. As a result, the expected results for mathematics lessons are still very low. The fact in this field shows that student mathematics learning outcomes are still low. This is similar to that expressed by [3] that SMK student achievement in learning mathematics is still relatively low. In addition, research was conducted [4] states that the low ability to solve and understand mathematical problems of MTs students shows the low KPMM of students. Likewise, with research conducted [5] that the low KPMM is caused by the low ability of mathematical understanding.

Therefore, teachers must find alternative learning that can be used to improve student mathematics learning outcomes for the better. The 2013 curriculum provides ample opportunities for teachers to use varied learning models. The learning that is carried out is not limited to the types of learning models that have been mentioned previously due to the fact there are many other learning models that can be used and facilitate students in following technological developments [6]. One way that teachers can do to improve student mathematics learning outcomes is by applying the Moodle-based Hybrid Learning model. In the Moodle-based Hybrid Learning model the implementation of learning is not only in the classroom, but learning is also done outside the classroom which is commonly referred to as online learning.

Research on hybrid learning models has been the concern of previous researchers [7]; [8]; and [6]. They provide an overview of the hybrid learning model of learning implementation not only in the classroom, but learning is also carried out outside the classroom commonly referred to as online learning; through the hybrid learning model, student activities become more numerous so students become active and student-centered learning; there is an influence of learning model Hybrid type Traditional Class-Real Workshop on the ability of mathematical understanding in terms of students' self-confidence; and there is an influence of hybrid learning models on students' mathematical communication on a cube and beam material in the experimental class. Hybrid Learning is oriented to provide the most effective and efficient experience possible by combining face-to-face meetings in the classroom with the development of e-Learning environments. This method is also the best alternative to increase the effectiveness, 
attractiveness and greater efficiency so that they can interact between humans and diverse learning environments. Hybrid Learning also provides opportunities to become better separately and together, as well as at the same time and separately. The application of Hybrid Learning can improve mutuality and the quality of learning. This learning can show a better difference in terms of motivation, interests, and student learning outcomes compared to other methods, especially methods in direct learning [9] so the Hybrid Learning method successfully becomes a learning trend. The online learning can be done by using the Moodle application, wherein one study group can provide information to other groups verbally, current and concretely. The use of Moodle when the learning process can be carried out significantly will foster a competitive education, because each study group will display its excellence so that quality education is made continuously. The existence of Moodle learning activities can be done anytime and anywhere, as long as students have an internet network. The interaction between students and teachers will be increasingly well established. The application of the Moodle-based Hybrid Learning model does not just happen, but it takes consideration of the characteristics of the learning objectives, the subject and selecting and determining which activities are relevant for conventional learning and which activities are relevant for online learning. Therefore, learning will be more fun and students will be guided to learn independently by the teacher.

Three recent studies of hybrid learning as written above, are limited to describing the effect of hybrid learning on mathematical understanding abilities in terms of students' self-confidence; and the effect of hybrid learning on students' mathematical communication. To that end, research on the development of student mathematics learning outcomes using Moodle-based hybrid learning has not been comprehensively discussed. Therefore, this article seeks to find meaning in several ways, namely: (1) describing student activities during the implementation of the Moodle-based Hybrid Learning model in mathematics learning; and 2) determine the effect of Moodle-based Hybrid Learning models on student mathematics learning outcomes.

\section{METHOD}

This article uses experimental research. The form of experiments in this study is a true experimental design that is by testing the learning approach studied and testing its effect on learning outcomes by comparing learning outcomes in the treatment group with the control group. The population in this study is basically all high school students in Riau. However, due to the vast area and the large number of population the sample taken in writing this article is SMA Negeri 1 Tembilahan Hulu to represent an area that is categorized as semi-city and the school has easy internet access and has a living environment that is not difficult to get access to the internet. In getting samples for each treatment and control group in each school selected according to the regional sample, a cluster sampling will be conducted of the number of classes in the school.

To obtain primary data from the field, in accordance with the design of the study, tests were used to measure student learning outcomes from each treatment group and the control group. To obtain certainty of data about the exact treatment of an experiment an observation technique will be used where the researcher will prepare an observation form that will be used in the experimental research. After each data is collected and tabulated, the data will be analyzed using parametric statistical analysis using simple linear regression using SPSS Program Version 18.00. Before carrying out a simple linear regression test of the requirements of the analysis has been carried out, it turns out that the distribution of data is normal and homogeneous. 


\section{RESULTS AND DISCUSSION}

As stated in Chapter I, this study aims to describe the activities of students during the implementation of hybrid learning in mathematics learning and find out the results of student mathematics learning through the application of Moodle-based Hybrid Learning models.

\section{Description of Student Activities During the Implementation of the Moodle-based Hybrid Learning model}

This research was conducted by experimenting with Moodle-based Hybrid Learning models for students of class XI Science in SMA Negeri 1 Tembilahan Hulu. In accordance with the conditions of the school, this experiment was carried out for one month. In approximately two weeks, tests were conducted on each school for the purposes of determining the experimental class and the control class, then the two research groups were given different treatments, namely the experimental group obtained Hybrid Learning and the control group with conventional learning. Furthermore, at the end of the study a post-test was conducted on the two groups. In the control group, learning is done conventionally, but researchers still give direction to the teacher who teaches and controls the implementation of learning. This is done so that learning in the control group does not deviate from the research objectives, for example in terms of the material being taught must be adapted to the material in the experimental group and the learning time must also be adjusted so that it is completed relatively simultaneously with the learning time in the experimental class, so that the posttest can be done at the same time.

Student activities in undergoing the learning process is one of the keys to the success of achieving educational goals. Activity is the most important principle of didactic principles because self-study is an activity and without an activity it is impossible for a person to learn. The activity itself is not only physical activity but also the mental psychic activity of the learner who is involved together in a learning process. Therefore, learning activities that are capable of involving these two types of activities will be able to determine the level of student learning outcomes. Based on the results of research conducted on students in Tembilahan Hulu High School 1 which are different as the subject of this research, the fact that the learning activities of students using Hybrid Learning can be seen in Table 1 below:

Table 1. Recapitulation of Hybrid Learning Implementation Results

\begin{tabular}{cll}
\hline No. & \multicolumn{1}{c}{ Class } & Value \\
\hline 1 & Eksperiment & 19,97 \\
2 & Control & 17,52 \\
\hline
\end{tabular}

Based on table 1 above, it can be seen that the activities of Moodle-based Hybrid Learning models in mathematics in the experimental and control classes are in the high category. The experimental class is in the high category with an average of 19.97 and the control class is also in the high category with an average of 17.52. Thus, it can be said that there is a difference in the activities of the Moodle-based Hybrid Learning model for each group and seen from the category of student activities consisting of high categories. For more details, can also be seen in the following bar diagram 1 below. 


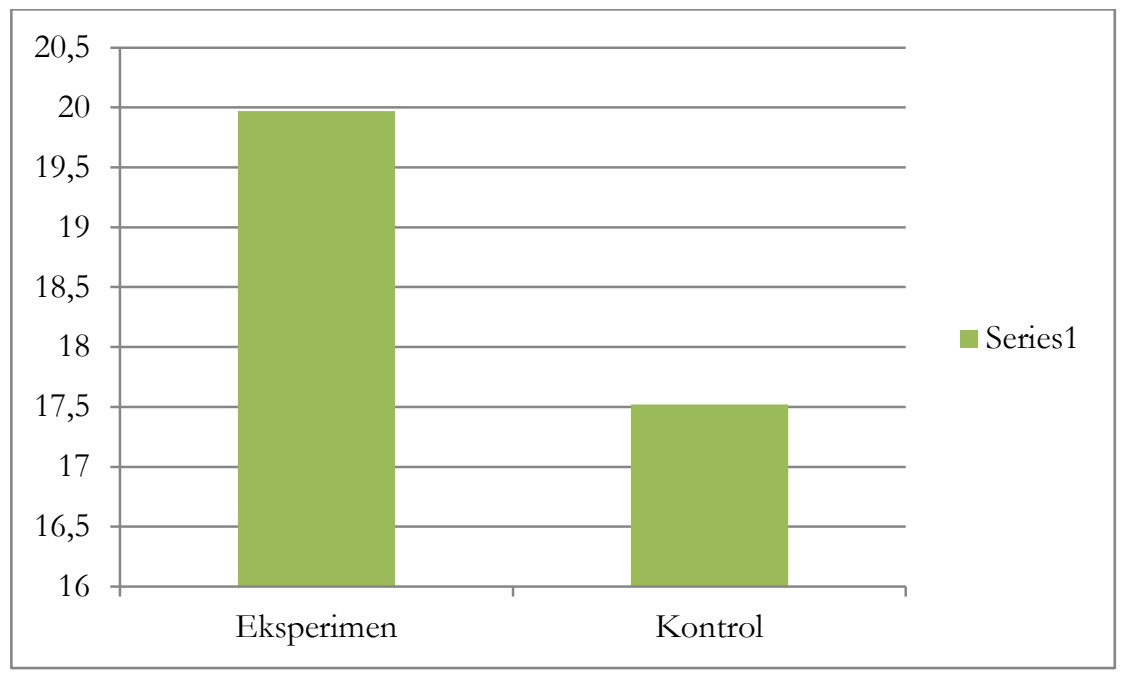

Figure 1. Student Activity Diagram Through Moodle-based Hybrid Learning Models

\section{Student Mathematics Learning Outcomes Using the Moodle-based Hybrid Learning Model}

The data to be analyzed is data from student learning outcomes by applying the Moodlebased Hybrid Learning model and comparing the learning outcomes with the control class that uses conventional. Data analysis was performed using a simple linear regression test. But in conducting the $\mathrm{t}$ test there are two conditions that must be met, namely the normality and homogeneity test.

\section{Normality test}

The results of the normality test data on the results of mathematics learning outcomes are summarized in table 2 .

\begin{tabular}{lccc}
\multicolumn{4}{c}{ Table 2. Normality Test } \\
\hline Class & $\begin{array}{c}\text { Asymp. Sig. (2- } \\
\text { tailed) }\end{array}$ & $\alpha$ & Criteria \\
\hline Eksperiment & 0.441 & 0.05 & Normal \\
\hline Control & 0.717 & 0.05 & Normal
\end{tabular}

The calculation results contained in Table 2 show that the significant value of each group, namely the experimental class, is 0.441; and the control class is 0.717. Considering the significance value of the two groups is greater than 0.05 , it is concluded that the experimental class and control class data are normally distributed. In connection with these results, then to test the research hypothesis.

\section{Homogeneity Test}

The homogeneity test that researchers do is a variant test, homogeneity testing that researchers do is testing with learning outcomes test data. Homogeneity test results of mathematics learning outcomes are summarized in the following table 3.

Table 3. Homogeneity Test

\begin{tabular}{crrr}
\hline Levene Statistic & df1 & df2 & \multicolumn{1}{c}{ Sig. } \\
\hline 1.013 & 1 & 64 & .318 \\
\hline
\end{tabular}


The calculation results contained in Table 3 show that the significance value of the posttest data of the learning outcomes of the experimental class and the control class of each group is 0.318 , which is greater than 0.05 . Thus, it was concluded that the posttest data were mathematical learning outcomes of students in the experimental class and homogeneous control class. In connection with that, to test the differences in students' mathematical learning outcomes the $t$ test was used through the SPSS 18.00 program.

\section{Hypothesis testing}

The hypotheses tested are:

$\mathrm{H}_{0}$ : There is an influence of the Moodle-based Hybrid Learning model on student mathematics learning outcomes

$\mathrm{H}_{1}$ : There is no influence of Moodle-based Hybrid Learning models on student mathematics learning outcomes

In this case, $\mathbf{H}_{0}$ will be rejected if the value is significant $>0.05$. The results of the calculation of the above hypothesis test are summarized in Table 4 below.

Table 4. Hypothesis Testing

\begin{tabular}{|c|c|c|c|c|c|}
\hline Class & $\mathrm{N}$ & Mean & Std. Deviasi & $\alpha$ Sig. & Information \\
\hline Eksperiment & 33 & 19,97 & 5.682 & \multirow{2}{*}{.036} & \multirow{2}{*}{$\mathrm{H}_{0}$ received } \\
\hline Control & 33 & 17,52 & 4.816 & & \\
\hline
\end{tabular}

The calculation results contained in Table 4 show that the significance value of the posttest data test in mathematical learning outcomes between students whose learning uses the Moodlebased Hybrid Learning model and conventional learning is smaller than $0.05(0.036<0.05)$. This means that H_O is accepted, so it can be concluded that there is an influence of Moodle-based Hybrid Learning models on student mathematics learning outcomes. In other words, students' mathematical learning outcomes are better at using Moodle-based Hybrid Learning models than using conventional learning. The results of hypothesis testing provide a conclusion that there are differences in mathematical learning outcomes between students who learn to use hybrid learning and students who learn to use conventional learning. The learning outcomes of students who get Moodle-based hybrid learning are better than students who get conventional learning. Learning through Moodle-based hybrid learning can actually provide convenience for students in using technology, with this convenience can reduce the introduction of Moodle-based hybrid learning itself. Therefore, the role of the teacher in this case is required to have mastery of the use of the internet, provide guidance to students in searching and finding sites that are relevant to learning material, providing presentation of material through the web that is interesting and desirable, providing guidance and communication services through internet, and have other skills needed. Based on these explanations we can understand that learning by utilizing technology in this case Moodle-based hybrid learning can help students be more efficient in learning.

These results are relevant to the results of research conducted [10] that there are differences in learning outcomes between students who are taught blended learning (hybrid learning) compared to students who are taught with conventional learning. The results of this study are also strengthened by research conducted by [11] stating that there is an increase in the mastery of student material as well as an increase in the quality of students' thinking. This is also in line with the statement [12] that there are significant differences in mathematical power 
between students who study through full e-learning, blended-learning, and conventional learning. Furthermore, [13] that the mathematical communication skills of students in hybrid (blended) learning are classified as good. The results of this study also have similarities with research conducted by [14] that the implementation of Hybrid Cooperative Learning in learning in Riau Province High School in mathematics subjects is in the high category as well as in sociology subjects; Student activities in learning Hybrid Cooperative Learning in SMA Riau Province are better and student activities in sociology subjects are higher than mathematics subjects. Based on several research results on student learning outcomes, it can be understood that students whose learning with Moodle-based Hybrid Learning provides improved results that are better than conventional learning. This is because learning done in class has undergone a change from the teacher-centered learning paradigm to student-centered learning to build student knowledge independently through problem challenges, discovery activities, and work in small groups. The teacher recognizes that this method is something new for them, so that at the beginning of student learning even teachers are still confused in applying it. This can be seen from the first meeting that has not been going well, but at the next meeting learning begins to run well as expected, and student activities have shown progress starting from the discovery activity until finally students can present their findings in front of the class.

\section{CONCLUSIONS AND SUGGESTIONS}

Based on the results of previous studies and discussions, it is concluded that students who get learning with Moodle-based hybrid learning models get better achievement in learning outcomes, compared to students who get conventional learning. That is, there is an influence of the Moodle-based Hybrid Learning model on student mathematics learning outcomes. Based on the conclusions above, the following suggestions can be given: 1) With the influence of the Moodle-based Hybrid Learning model on student mathematics learning outcomes, the teacher is able to foster students who are more willing to express and accept opinions in learning to solve problems; 2) The teacher acts as a facilitator in the Moodle-based Hybrid Learning model; and 3) Teachers should be able to use appropriate learning in learning activities.

\section{ACKNOWLEDGEMENTS}

A big thank you to the authors convey to various parties who have provided a lot of input towards writing the results of this research article, especially the editors. Thank you also to the Journal Team ... for publishing this article. Hopefully, this article can be useful for readers and make inspiration for further research.

\section{REFERENCES}

[1] Nurdalilah, "Pengaruh Model Pembelajaran Kooperatif Tipe Hibrid terhadap Kemampuan Komunikasi Matematika Siswa Kelas VIII SMP Negeri 1 Kotanopan,” EKSAKTA J. Penelit. dan Pembelajaran MIPA, vol. 3, no. 2, pp. 25-29, 2018.

[2] N. Wahyuddin, "Efektivitas Pembelajaran Matematika Melalui Pembelajaran Aktif Tipe Everyone Is A Teacher Here (ETH) Pada Siswa Kelas X SMA Negeri 8 Takalar," AlKhawarizmi J. Pendidik. dan Pembelajaran Mat., vol. 2, no. 1, pp. 72-105, 2018.

[3] Tina Sri Sumartini, "Peningkatan Kemampuan Pemecahan Masalah Matematis Siswa 
melalui Pembelajaran Berbasis Masalah," Mosharafa J. Pendidik. Mat., vol. 8, no. 3, pp. 148158, 2016.

[4] Susanti, "Meningkatkan Kemampuan Pemecahan Masalah Matematis dan Self-Efficacy Siswa MTs Melalui Pendekatan Pendidikan Matematika Realistik," Suska J. Math. Educ., vol. 3, no. 2, pp. 92-101, 2017.

[5] S. Ulvah and E. A. Afriansyah, "Kemampuan Pemecahan Masalah Matematis Siswa ditinjau melalui Model Pembelajaran SAVI dan Konvensional," J. Ris. Pendidik., vol. 2, no. 2, pp. 142-153, 2016.

[6] N. E. Z. Yoni Sunaryo, Ida Nuraida, "Pengaruh Model Pembelajaran Hybrid Tipe Traditional Clasess-Real Workshop terhadap Kemampuan Pemahaman Matematik ditinjau Dari Self-Confidence Siswa," J. Teor. dan Ris. Mat., vol. 2, no. 2, pp. 93-100, 2018.

[7] M. Nurul Faizah, Sunismi, "Pengembangan Model Pembelajaran Hybrid E-Learning Tutor Sebaya Berbasis Media Blog Pada Materi Matriks untuk Kelas XI," JP3 Jurnal Penelitian, Pendidik. dan Pembelajaran), vol. 13, no. 2, 2019.

[8] Ino Angga Putra, "Orientasi Hybrid Learning Melalui Model Hybrid Learning Dengan Bantuan Multimedia Di Dalam Kegiatan Pembelajaran,” EDUSCOPE, vol. 1, no. 1, pp. 36-42, 2015.

[9] M. Yunika Lestaria Ningsih, Misdalina, "Peningkatan Hasil Belajar dan Kemandirian Belajar Metode Statistika Melalui Pembelajaran Blended Learning," Al-jabar J. Pendidik. Mat., vol. 8, no. 2, pp. 155-164, 2017.

[10] S. B. Sjukur, "Pengaruh Blended Learning terhadap Motivasi Belajar dan Hasil Belajar Siswa SMK," J. Pendidik. Vokasi, vol. 2, no. 3, pp. 368-378, 2012.

[11] Mehmet Sahin, "Blended Learning in Vocational Education : An Experimental Study," Int. J. Vocat. Tech. Educ., vol. 2, no. 6, pp. 95-101, 2010.

[12] R. P. Yaniawati, "Pengaruh E-Learning untuk Meningkatkan Daya Matematik Mahasiswa," Cakrawala Pendidik., vol. XXX1, no. 3, pp. 381-393, 2012.

[13] S. Rizqi, Afria Alfitri, Hardi Suyitno, "Analisis Kemampuan Komunikasi Mamtematis ditinjau Dari Kperecayaan Diri Siswa Melalui Blended Learning," Unnes J. Math. Educ. Res., vol. 5, no. 1, pp. 17-23, 2016.

[14] K. M. Zulkifli Nelson, Musa Thahir, "Kajian Pengembangan Pembelajaran Model Active Knowledge Sharing dan Team Asissted Individualization dalam Mendukung Andragogi untuk Meningkatkan Hasil Belajar Siswa SMA di Propinsi Riau," Suska J. Math. Educ., vol. 2, no. 1, pp. 67 - 75, 2016. 